\title{
Interferon- $\tau$ upregulates prolactin receptor mRNA in the ovine endometrium during the peri-implantation period
}

\author{
C Martin, L Pessemesse, MP de la Llosa-Hermier ${ }^{1}$, J Martal ${ }^{1}$, J Djiane and M Charlier \\ Neuroendocrinologie Moléculaire de la Prise Alimentaire and ${ }^{1}$ Biologie du Développement et de la Reproduction, \\ Institut National de la Recherche Agronomique, 78350 Jouy-en-Josas, France
}

Correspondence should be addressed to M Charlier; Email: charlier@jouy.inra.fr

\begin{abstract}
Our objective was to determine the effect of ovine interferon- $\tau$ (IFN- $\tau$ ) on prolactin receptor (PRL-R) gene expression in the ovine endometrium. IFN- $\tau$ is an embryonic cytokine which, via its paracrine anti-luteolytic activity, plays a critical role in maternal recognition of pregnancy in ruminants. Using ribonuclease protection assay procedures, we compared endometrial PRL-R mRNA levels in ewes that were intrauterine injected with either $\mathbf{2} \mathrm{mg}$ bovine serum albumin or $2 \mathrm{mg}$ recombinant ovine IFN- $\tau$ on day 10 of the oestrous cycle (day $0=$ day of oestrus). IFN treatment significantly increased the abundance of both the long and short forms of PRL-R mRNA in the ovine uterus, but had no effect on the long:short form ratio. In situ hybridization experiments revealed that the increase in abundance of PRL-R mRNA in the uterus was localized to the glandular compartment of the endometrium. In pregnant ewes, a similar increase in PRL-R mRNA abundance was found to occur in ovine endometrium on days 14-15 post conception. Collectively, these data provided strong evidence that IFN- $\tau$ modulates the level of lactogenic hormone receptor mRNA in the ovine uterus. Whether the effect of IFN- $\tau$ on PRL-R expression is mediated directly or influenced, at least in part, by progesterone remains to be elucidated.
\end{abstract}

Reproduction (2004) 128 99-105

\section{Introduction}

Implantation of the conceptus is a critical developmental step in mammalian reproduction and involves a complex interaction between embryonic trophectodermal cells and receptive maternal endometrium. During implantation, the uterus undergoes remodelling to create an optimized environment for embryonic and foetal growth. The generation of this remodelled receptive endometrium is dictated by various factors including peptides, steroid hormones, cytokines and growth factors, which are sequentially secreted by both embryonic and maternal tissues. A major messenger in the communication that occurs between the conceptus and the endometrium of sheep is the type I interferon- $\tau(\mathrm{IFN}-\tau)$, which is anti-luteolytic and transiently secreted by the extra-embryonic trophectoderm during the peri-implantation period (days 12-21 of pregnancy) (Martal et al. 1979, Hansen et al. 1988). IFN- $\tau$ exerts a paracrine effect on the uterine epithelium to suppress oestrogen and oxytocin receptor gene expression, which prevents pulsatile production of prostaglandin $F_{2 \alpha}$ and subsequent luteolysis (Bazer et al. 1996, Martal et al. 1997, 1998).

In sheep, implantation occurs by day 15 of pregnancy and is coincident with onset of binucleate-trophectodermal cell production of the prolactin (PRL)- and growth hormone (GH)-related hormone, placental lactogen (PL) (Martal et al. 1977, Wooding et al. 1992). Moreover, local production of $\mathrm{PRL}$ and the presence of $\mathrm{PRL}$ receptors (PRL-R) in the pregnant uterus of a number of species, including sheep (Cassy et al. 1999), provide the opportunity for PRL to have a direct effect on the uterus. The precise role of lactogenic hormones (PRL/PL) in the foetomaternal environment is currently unknown. One hypothesis is that lactogenic hormones are not only involved in endometrial-glandular-epithelial hypertrophy and differentiation (Chilton \& Daniel 1985, Gray et al. 2001a), but also in influencing uterine secretions (Young et al. 1989, Randall et al. 1991). Because implantation is a process involving a precise synchronization between blastocyst development and uterine receptivity, lactogenic hormones may constitute essential factors in the dialogue between mother and conceptus during this critical period. Indeed, Ormandy et al. (1997) demonstrated, using PRL-R knockout mice, that lactogenic hormones play a major role in embryonic development and in the implantation process.

In the present study, we have hypothesized that IFN- $\tau$ may be involved in the regulation of lactogenic hormone receptor mRNA levels in the ovine endometrium during early pregnancy. We thus provide the first in vivo evidence that IFN- $\tau$ is able to upregulate PRL-R gene 
expression in the ovine endometrium. A quantitative analysis of the two forms of PRL-R mRNA levels was first conducted by ribonuclease protection assay, and then spatially confirmed by in situ hybridization. Moreover, using ribonuclease protection assay procedures we report that transcription levels of both long and short PRL-R forms increase during the time of maternal recognition of pregnancy.

\section{Materials and Methods}

\section{Animals, surgery and experimental procedure}

All procedures relating to the care and use of animals were approved by the French Ministry of Agriculture in accordance with the French regulations for animal experimentation (guideline 19/04/1988). This study was performed using 18 primiparous Préalpes du Sud ewes. Oestrous cycles were synchronized as previously described (Cassy et al. 1998). Ewes were assigned to the following experimental groups. (1) Ewes were slaughtered on days $7-8(n=4)$ or $14-15$ $(n=5)$ following a fertile mating. At the time of slaughter, the presence of a conceptus was identified to confirm that the ewes were pregnant. (2) Control ewes $(n=3)$ were exposed to non-fertile rams and received a single intrauterine injection of $2 \mathrm{mg}$ bovine serum albumin (BSA) diluted in $0.9 \% \mathrm{NaCl}(1 \mathrm{ml})$ on day 10 of the oestrous cycle. (3) Ewes in the treated group (IFN- $\tau ; n=6$ ) received a single intrauterine injection of $0.9 \% \mathrm{NaCl}(1 \mathrm{ml})$ with $2 \mathrm{mg}$ recombinant IFN- $\tau$ (Institut National de la Recherche Agronomique, Dijon, France; $\left.10^{8} \mathrm{IU} / \mathrm{mg}\right)+2 \mathrm{mg}$ BSA in the uterine horn adjacent to the corpus luteum on day 10 of the oestrous cycle and were slaughtered 6 days later when uterine horns were collected and prepared for subsequent analysis. To verify the maintenance of luteal function, daily blood samples were collected by jugular venipuncture and progesterone concentrations were measured by radioimmunoassay as described by Heyman et al. (1984).

\section{Preparation of the hybridization probes}

Two recombinant Bluescript $\mathrm{SK}(-)$ transcription vectors (Stratagene, Amsterdam, The Netherlands) containing either the $324 \mathrm{bp}$ Aflll-Xbal fragment of the ovine PRL-R cDNA as described by Cassy et al. (1998) or the full-length ovine PRL-R CDNA were used to perform, respectively, ribonuclease protection assay and in situ hybridization. After linearization, antisense and sense cRNA probes were further transcribed using either T3 or T7 RNA polymerases (Invitrogen, Cergy-Pontoise, France) and labelled with $\left[\alpha-{ }^{35}\right.$ S]UTP (>1000 Ci/mmol; Amersham, Saclay, France) for in situ hybridization or $\left[\alpha-{ }^{32} \mathrm{P}\right]$ UTP $(800 \mathrm{Ci} / \mathrm{mmol}$; Amersham) for ribonuclease protection assay. Ovine fulllength PRL-R sense cRNA probe was used as a negative control for in situ hybridization. For ribonuclease protection assays, all results were normalized using a pGEM-T (Promega, Charbonnières-les-Bains, France) vector containing a $110 \mathrm{bp}$ fragment of the ovine glyceraldehyde-3-phosphate dehydrogenase (GAPDH) housekeeping gene (Cassy et al. 2000).

\section{Tissue preparation and RNA extraction}

Total RNA extraction from ovine endometrium was performed by the guanidium-isothiocyanate method as previously described by Chomczynski \& Sacchi (1987) and as modified by Puissant \& Houdebine (1990). Poly $(A)+$ RNA was then isolated using the poly $(A)+$ RNA isolation kit (R\&D System, Abingdon, Kent, UK) according to the manufacturer's instructions. For in situ hybridization, intercaruncular endometrial tissue was cut and fixed in $1 \%$ paraformaldehyde for $24 \mathrm{~h}$ at $4{ }^{\circ} \mathrm{C}$, cryoprotected in a $15 \%$ sucrose solution overnight, and frozen with Tissue-Tek (Leica, Rueil Malmaison, France) at $-45^{\circ} \mathrm{C}$ in isopentane cooled on dry ice. Tissues were then stored at $80^{\circ} \mathrm{C}$ until use.

\section{In situ hybridization}

Seven micrometer cryostat sections of endometrium were mounted onto Superfrost/Plus slides (Prolabo, Fontenaysous-Bois, France), postfixed in 4\% paraformaldehyde, washed in $4 \times$ SSC $(1 \times$ SSC: $150 \mathrm{mM}$ sodium chloride and $15 \mathrm{mM}$ sodium citrate, $\mathrm{pH} 7$ ), acetylated in a $4 \times$ SSC solution containing $0.25 \%$ anhydride acetic and $0.1 \mathrm{M}$ triethanolamine, dehydrated in ethanol and air dried. Each slide received $50 \mu \mathrm{l}$ of the hybridization mixture described by Cassy et al. (1998, 2000) and contained $2 \times 10^{7}$ c.p.m./ml sense or antisense cRNA probe. Slides were then incubated overnight at $55^{\circ} \mathrm{C}$ in a moist chamber before a 30-min RNase A $(20 \mu \mathrm{g} / \mathrm{ml}$ in $4 \times$ SSC) treatment. After successive washings in decreasing concentrations of SSC at room temperature, slides were placed sequentially in two baths of $0.1 \times \mathrm{SSC}$ at $65^{\circ} \mathrm{C}$ for $30 \mathrm{~min}$ each and dehydrated in ethanol. Dried slides were processed for autoradiography using NTB2 photographic emulsion (Eastman KODAK Européenne d'Imagerie Scientifique, Massy, France) and exposed for $2-4$ weeks at $4{ }^{\circ} \mathrm{C}$. Sections were then stained with toluidine blue and examined with a Reichert microscope equipped with an epiillumination system and a polarizing filter (Leica, Rueil Malmaison, France).

\section{Ribonuclease protection assay}

The ribonuclease protection assay was carried out as described by Sambrook et al. (1989). Briefly, $20 \mu \mathrm{g}$ tRNA or $5 \mu \mathrm{g}$ poly $(\mathrm{A})+$ RNA were hybridized in $30 \mu \mathrm{l}$ hybridization buffer (80\% formamide, $40 \mathrm{mM}$ Pipes, pH 6.4, $0.4 \mathrm{M}$ $\mathrm{NaCl}$ and $1 \mathrm{mM}$ EDTA) containing $10^{6}$ c.p.m. of the $\left[\alpha^{32}\right.$ P]UTP-labelled probe. The mixture was heated at $85^{\circ} \mathrm{C}$ for $10 \mathrm{~min}$ and incubated overnight at $37^{\circ} \mathrm{C}$. Samples were then digested with $16 \mu \mathrm{g} / \mathrm{ml}$ RNase $\mathrm{A}$ and $0.8 \mu \mathrm{g} / \mathrm{ml}$ RNase $\mathrm{T} 1$ for $1 \mathrm{~h}$ at $15^{\circ} \mathrm{C}$, and with $300 \mu \mathrm{g} / \mathrm{ml}$ proteinase $\mathrm{K}$ for $30 \mathrm{~min}$ at $37^{\circ} \mathrm{C}$. Protected RNA hybrids were 
extracted, precipitated and resuspended in water. After denaturation, hybrids were loaded on a $6 \%$ acrylamide sequencing gel containing $8 \mathrm{M}$ urea and visualized by autoradiography. Various controls were performed by incubating the probe with $50 \mu \mathrm{g}$ yeast tRNA, and with or without RNase treatment. Signals were finally quantified using a STORM-860 scanner (Molecular Dynamics, Bondoufie, France) and ImageQuaNT software.

\section{Results}

\section{Maintenance of luteal function after ovine IFN- $\tau$ injection}

In order to verify the anti-luteolytic effect of IFN- $\tau$, serum progesterone was measured in control and injected ewes on day 10 of the oestrous cycle. As shown in Fig. 1, serum progesterone concentrations dropped in the control group (ewes 1, 2 and 3) from days 14 to 15 of the oestrous cycle to less than $1 \mathrm{ng} / \mathrm{ml}$ between days 15 and 16 . Intrauterine administration of $2 \mathrm{mg}$ recombinant olFN- $\tau$ had a significant effect on the maintenance of luteal function since ewes 4, 5, 6, 7, 8 and 9 exhibited a progesterone concentration higher than $3 \mathrm{ng} / \mathrm{ml}$ on day 16 .

\section{Effect of IFN- $\tau$ on PRL-R gene expression in ovine endometrium}

The $324 \mathrm{bp}$ AfllI-Xbal cDNA fragment, including at its $3^{\prime}$ end the $39 \mathrm{bp}$ insertion characteristic of the short form of
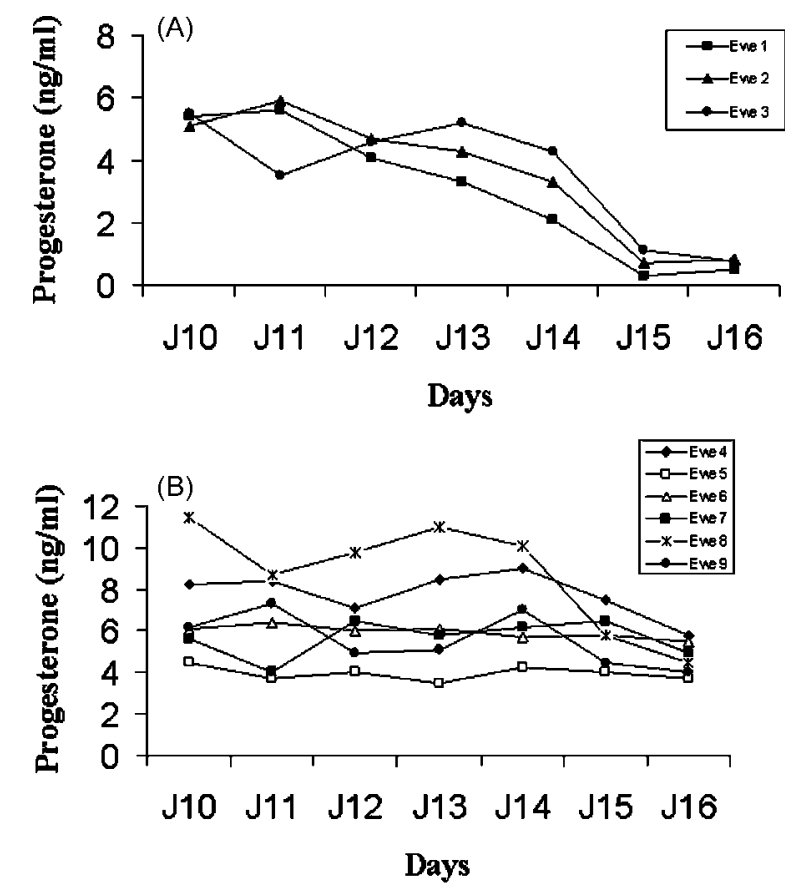

Figure 1 Progesterone concentrations $(\mathrm{ng} / \mathrm{ml})$ in peripheral serum of cyclic recipient ewes after intrauterine injection of (A) $2 \mathrm{mg} \mathrm{BSA}$ or (B) $2 \mathrm{mg}$ recombinant ovine IFN- $\tau$ on day 10 of oestrus. the ovine PRL-R cDNA, enabled us to detect simultaneously both long and short forms of the ovine PRL-R. As expected, two cRNA fragments of sizes 324 and $285 \mathrm{bp}$, corresponding respectively to the short and the long forms of ovine PRL-R, were protected from RNase digestion in each ewe of the control and IFN- $\tau$-treated groups (Fig. 2A). When the ovine PRL-R CRNA probe was hybridized with non-specific RNA (yeast tRNA) and treated with RNases, no signal was detected on the gel (Fig. 2A, lane C2). Using STORM scanning, the relative proportions of both transcripts encoding the two forms of PRL-R were quantified and normalized. As is evident in Fig. 2B, IFN- $\tau$ treatment induced a dramatic increase $(\sim$ sixfold $)$ in abundance of the long and short forms of the PRL-R mRNA. Moreover, the ratio of the long to the short
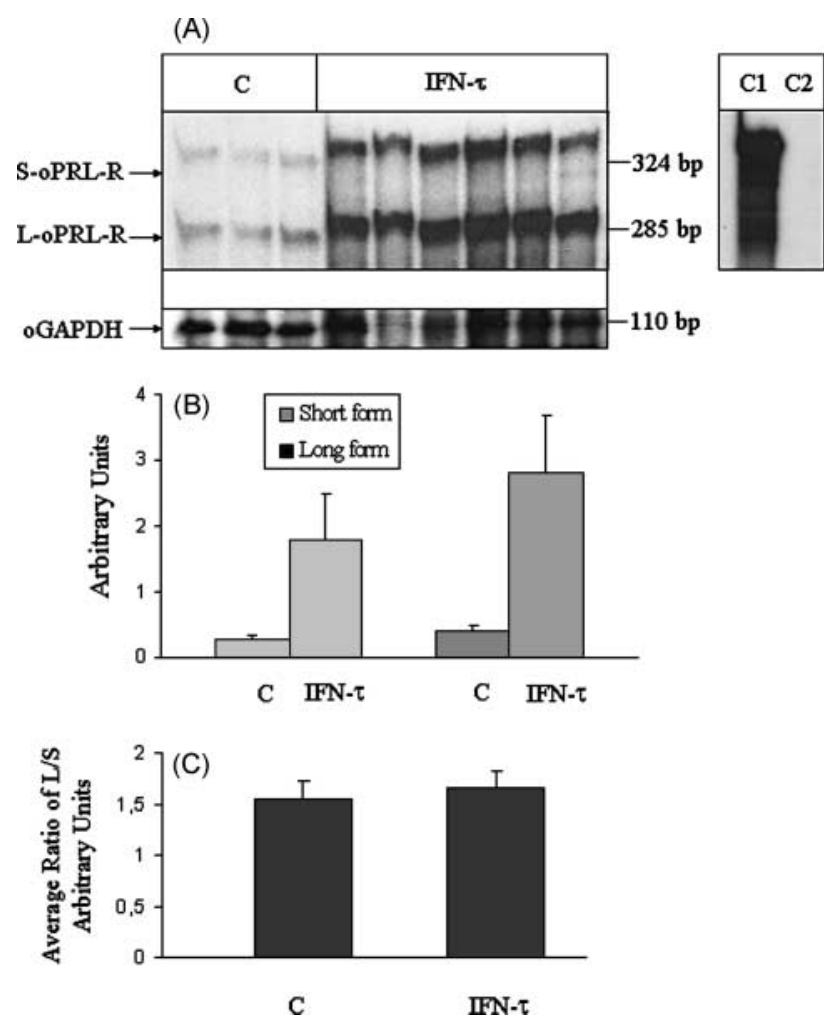

Figure 2 (A) Detection by ribonuclease protection assay of ovine (o) PRL-R mRNA in the endometrium of the BSA-treated control (C) and IFN- $\tau$-treated (IFN- $\tau$ ) ewes. The radiolabelled 324 bp PRL-R fragment, used as cRNA probe, was hybridized to $5 \mu$ g endometrial poly $(A)+$ RNA. Sizes of the protected fragments, calculated from a sequencing ladder, are indicated on the right. As controls, the ovine PRL-R cRNA probe was hybridized with yeast IRNA and then digested with RNases (lane C2) or not (lane C1). Each lane represents mRNA from individual ewes of each experimental group (S, short form; $L$, long form). (B) Normalized ratio of ovine PRL-R mRNA to oGAPDH mRNA determined after STORM quantification of the gel. Long and short forms of the PRL-R are indicated in control (C) and IFN- $\tau$ treated groups. (C) Changes in relative ratio of the long (L) to the short (S) ovine PRL-R mRNA in each experimental group. Results are expressed as means \pm S.E.M. of three or six animals respectively in the control (C) and IFN- $\tau$-treated groups. 
form of PRL-R mRNA remained similar in the control and IFN- $\tau$-injected groups, indicating that IFN- $\tau$ produces the same transcriptional enhancing effect on both forms of the PRL-R (Fig. 2C).

\section{Cellular localization of PRL-R mRNA in the endometrium of IFN- $\tau$-treated ewes}

In order to reaffirm our observation of enhanced expression of PRL-R mRNA in ovine endometrium after IFN- $\tau$ stimulation, in situ hybridization was carried out on both control and IFN- $\tau$-treated ewes. In control ewes, endometrial sections hybridized with an $\left[\alpha-{ }^{35} \mathrm{~S}\right]$-labelled ovine PRL-R cRNA antisense probe revealed a weak hybridization signal localized within the cells of the glandular epithelium (Fig. $3 \mathrm{~A}$ and $\mathrm{B})$. In contrast, a greater abundance of signal was observed in ewes treated with IFN- $\tau$ (Fig. 3C, D, E and F) and localized specifically in the deepest endometrial glands. No specific hybridization signal was observed in stromal cells of the intercaruncular endometrium in any ewe. Control tissue sections hybridized with a sense probe (Fig. 3G and $\mathrm{H}$ ) exhibited no specific signal, further demonstrating the specificity of the reaction. Thus, these data provided spatial evidence that IFN- $\tau$ was able to upregulate PRL-R mRNA expression in the glandular epithelial cells of the endometrium.

\section{Expression of PRL-R mRNA in ovine endometrium during the peri-implantation period}

In this study, the expression of the two forms of PRL-R mRNA was investigated in the endometrium of nine ewes on days 7-8 $(n=4)$ and 14-15 $(n=5)$ of pregnancy. These stages of pregnancy were chosen according to IFN- $\tau$ secretion patterns: just prior to IFN- $\tau$ production (days $7-8$ ) and during the maternal recognition of pregnancy interval when IFN- $\tau$ secretion is maximum (days $14-15$ ). The abundance of long and short form PRL-R mRNA were determined by ribonuclease protection assay (Fig. 4A). Using the 324 bpAfIII-Xbal PRL-R cDNA fragment as a probe and after STORM analysis, data are illustrated in Fig. 4B and presented as corrected values relative to the expression of
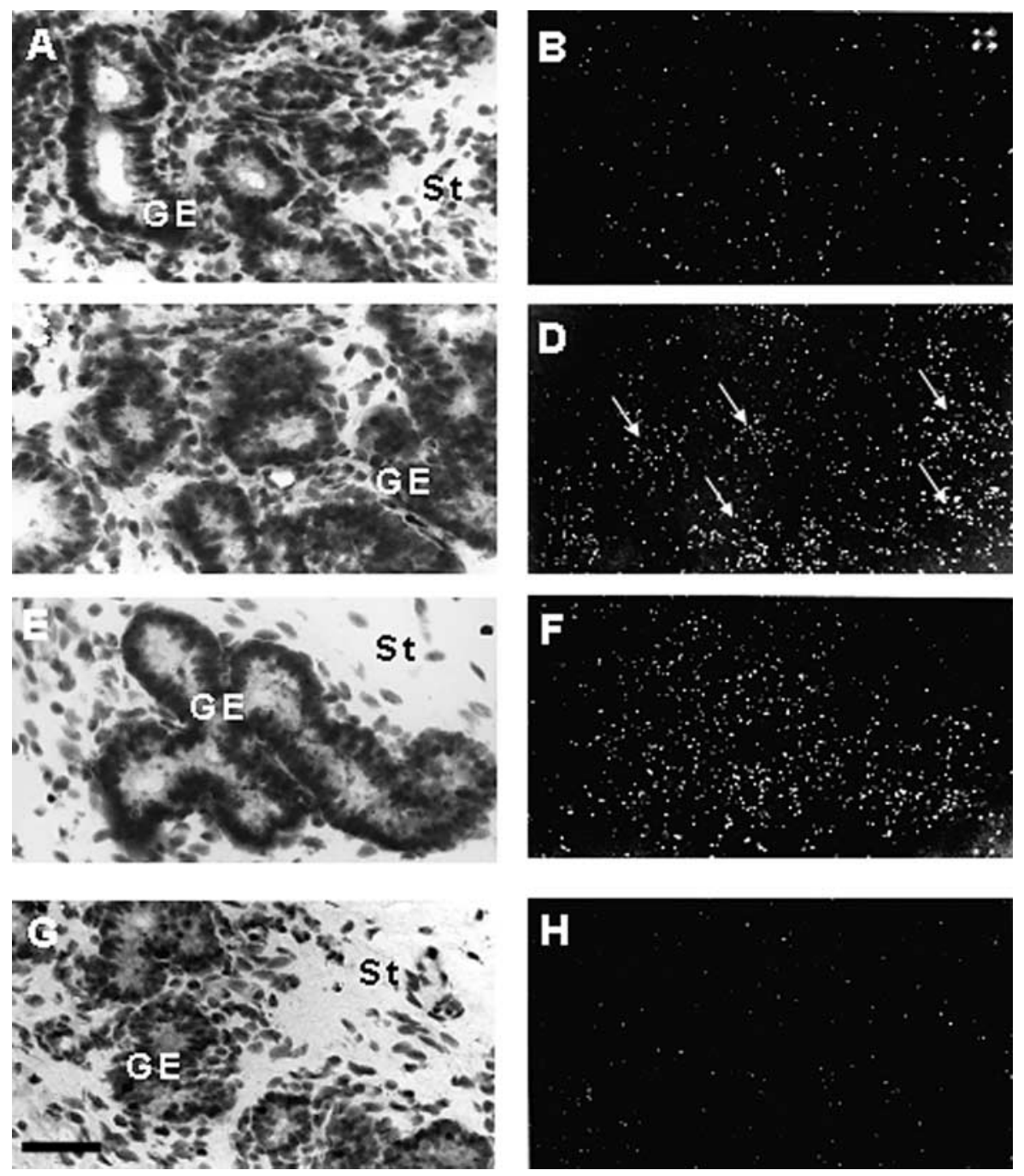

Figure 3 In situ hybridization analysis of ovine PRL-R gene expression in ovine endometrium of ( $\mathrm{A}$ and $\mathrm{B}) \mathrm{BSA}$-treated controls and (C, D, E and F) IFN- $\tau$-treated ewes. A section of endometrium was hybridized with the sense probe and used as a control of specificity ( $G$ and H). Left and right columns correspond respectively to brightfield and epi-illuminated micrographs. The glandular epithelium (GE) and the stroma (St) are illustrated. Bar $=50 \mu \mathrm{m}$. 
(A)
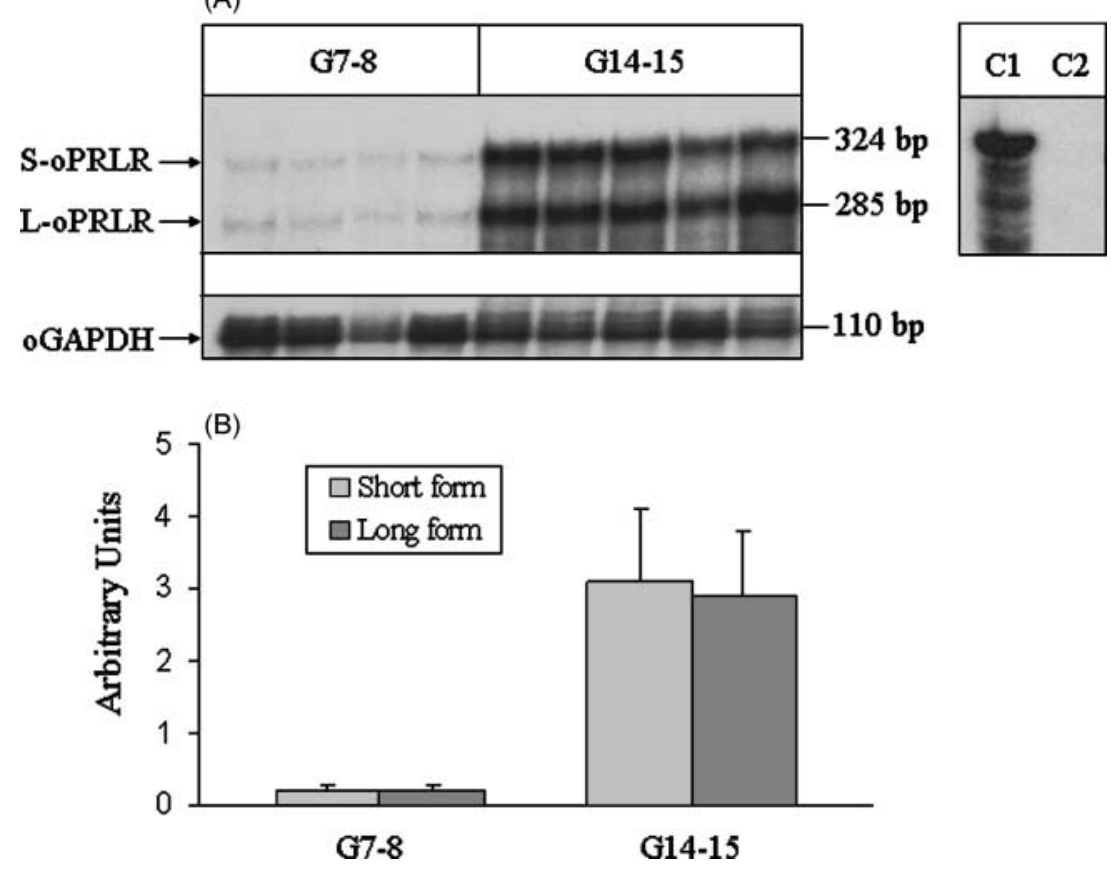

Figure 4 (A) Autoradiograph of ribonuclease protection assay products separated on a $6 \%$ polyacrylamide gel. tRNA $(20 \mu \mathrm{g})$ extracted from individual endometrial tissue on days $7-8$ $(\mathrm{G} 7-8, n=4)$ and $14-15$ (G14-15, $n=5)$ of pregnancy were hybridized with radiolabelled 324 bp antisense cRNA probe. Yeast tRNA was hybridized with the radiolabelled probe and subjected to the RNases (lane C2) or not (lane C1). Each lane represents mRNA from individual ewes of each experimental group. (B) Quantification was performed by STORM scanning of the protected fragments of the gel and are presented as the normalized ratio of ovine PRL-R mRNA to oGAPDH mRNA. Results are expressed as means \pm S.E.M. of four or five animals respectively in groups G7-8 and G14-15. the housekeeping gene, GAPDH. Both long and short forms of PRL-R mRNA increased $\sim 15$-fold between days 7-8 and 14-15 of pregnancy. Thus, it seems likely that IFN- $\tau$, a major embryonic factor secreted during this period, could play the role of a potent modulator of PRL-R transcription in ovine endometrium.

\section{Discussion}

The objective of this study was to investigate the levels of lactogenic hormone receptor mRNA during the periimplantation period in ovine endometrium and investigate putative inducers of lactogenic receptor expression. In previously published work (Cassy et al. 1999), we reported that the glandular epithelium of ovine endometrium was a potential target of PRL action during pregnancy. In our current work, herein, we report that transcription of the long and short forms of PRL-R were greater on days 14-15 than on days 7-8 in the pregnant uterine endometrium of the ewe. This result is consistent with the observations of Stewart et al. (2000) who determined, by slot blot analysis, an increase of endometrial PRL-R mRNA levels during pregnancy.

IFN- $\tau$ is the major embryonic cytokine required for pregnancy recognition and maintenance in ruminants, and it is highly, locally and transiently expressed in ewes during the peri-implantation period (from day 12 to day 21 of pregnancy). Moreover, IFN- $\tau$ is known to mediate various paracrine effects through type I IFN receptors expressed in endometrial cells (Knickerbocker \& Niswender 1989, Kaluz et al. 1996). Therefore, we hypothesized that IFN- $\tau$ may play the role of a putative regulator of PRL-R mRNA expression in endometrium. Using ribonuclease protection assay methods, we demonstrated that IFN- $\tau$ treatment increased the level of both the long and short forms of PRL-R mRNA. However, the ratio of the long to the short form of the PRL-R receptor is not altered in IFN- $\tau$-treated endometrium (the long form is preferentially expressed). These observations were reaffirmed by in situ hybridization analysis, which provided evidence that treatment of ewes with IFN- $\tau$ had a stimulatory effect on glandular endometrial PRL-R gene expression. Moreover, the abundance of endometrial PRL-R mRNA present in ewes injected with IFN- $\tau$ was comparable with that previously documented in uterine endometrial tissue collected from day-14 pregnant animals (Cassy et al. 1999).

Collectively, these data support the hypothesis that IFN- $\tau$ plays a critical role in inducing lactogenic hormone receptor mRNA expression in endometrium. Furthermore, the secretion of $\mathrm{PL}$, which is the main lactogenic hormone expressed during pregnancy in the ewe, occurs when IFN- $\tau$ is most abundantly secreted (days 14-15 of pregnancy). We suggest that the temporal relationship between the pattern of secretion of IFN- $\tau$ by the conceptus and the expression of PRL-R in the endometrium (especially the glandular endometrium) is paramount to the process of maternal receptivity to the conceptus. Mechanistically, IFN- $\tau$ is necessary for the expression of uterine milk protein (UTMP) and osteopontin (OPN): two endometrial proteins induced by PL in ovariectomized ewes (Spencer et al. 1999, Stewart et al. 2000). Thus, it appears that upregulation of uterine PRL-R mRNA is the link between IFN- $\tau$ secretion and lactogenic hormone target gene expression.

IFN- $\tau$ plays a key role in the maintenance of progesterone secretion by the corpus luteum during the process of maternal recognition of pregnancy in ruminants. It has 
been previously reported in the rabbit that a cross-interaction between PRL and progesterone occurs in the endometrium to regulate their own receptors, as well as the expression of other uterine genes such as uteroglobin (Chilton et al. 1988). Whether the effect of IFN- $\tau$ on PRL-R gene expression is mediated directly or influenced by progesterone is open to discussion. Indeed, in the ewe, progesterone receptors (PR) are undetectable in glandular epithelium cells from days 13 to 19 of pregnancy (Spencer et al. 1995, Stewart et al. 2000). The loss of PR gene expression appears to be required for glandular remodelling and differentiation in ovine endometrium (Spencer \& Bazer 2002). Therefore, it seems more likely that the increase in endometrial PRL-R gene expression after IFN- $\tau$ treatment results from the direct action of IFN $-\tau$ rather than indirectly in conjunction with the influence of continued luteal secretion of progesterone. Nevertheless, in our experiments, serum progesterone levels were high in all IFN- $\tau$-injected animals. Moreover, Spencer et al. (1999) suggested that the combined presence of progesterone and IFN- $\tau$ is essential for ovine PL stimulation of endometrial UTMP and OPN gene expression. Taken together, these arguments do not show a direct or progesterone-mediated effect of IFN- $\tau$ on PRL-R gene expression.

The precise function(s) of the lactogenic hormones (PL/PRL) during pregnancy have not been elucidated. The hypothesis that lactogenic hormones could play a crucial role in maintaining gestation and implantation was supported by the work of Ormandy et al. (1997) using PRL-R knockout mice. Furthermore, enhancing the bioactivity of ovine PL results in increased birth weight of lambs and milk production by the ewes (Leibovitch et al. 2000). It is now established that ruminant PLs have the ability to bind both PRL-R and $\mathrm{GH}$ receptor $(\mathrm{GH}-\mathrm{R})$ (Herman et al. 2000). Several studies provide evidence that a transient homodimerization of PRL-R occurs in response to ruminant PL (Gertler et al. 1996, Sakal et al. 1997) and, more recently, the functional heterodimerization of PRL-R and GH-R by PL has been demonstrated in vitro (Herman et al. 2000, Biener et al. 2003) and in the ovine endometrium (Noel et al. 2003). Although it has been established that $\mathrm{GH}-\mathrm{R}$ was expressed throughout pregnancy in the endometrium (Lacroix et al. 1999), no precise quantitative study has been reported for GH-R mRNA expression during the peri-implantation period. Studies performed by Spencer et al. (1999) reported that the effects of $\mathrm{GH}$ on endometrial function require IFN- $\tau$. Thus, it seems likely that IFN- $\tau$ could also regulate endometrial GH-R gene expression during the peri-implantation period.

Glandular epithelium undergoes intense proliferation and differentiation during pregnancy (Gray et al. 2001a), which results in an abundance of secretory activity. Even partially characterized, glandular secretions are now considered to play major roles not only in maintaining gestation but also in nutrition, growth and immunoprotection of the foetus. The uterine gland knockout phenotype supports the hypothesis that endometrial glands are required for successful pregnancy, since uterine gland knockout ewes are unable to complete the normal gestational process (Gray et al. 2001b).

In summary, it is now established that numerous cytokines (IFN- $\tau, \mathrm{PL}$, ovine PRL and placental $\mathrm{GH}$ ) and sex steroids act sequentially on the ovine endometrium and are involved in growth, differentiation and secretory function of endometrial glands during gestation and foetal development. Among them, IFN- $\tau$ plays a pivotal role in the establishment of pregnancy, not only as the major signal for maternal recognition of pregnancy in ruminants, but also as the inducer of several endometrial proteins that may be critical for survival of the developing embryo. According to our findings, the PRL-R is upregulated by IFN- $\tau$ during early pregnancy, thus preparing the endometrium for the actions of lactogenic hormones, which have yet to be elucidated.

\section{Acknowledgements}

The authors are deeply grateful to Dr D H Keisler for critical discussion and revision of the manuscript and to $\mathrm{N}$ Charpentier for technical assistance.

\section{References}

Bazer FW, Spencer TE \& Ott TL 1996 Placental interferons. American Journal of Reproductive Immunology 35 297-308.

Biener E, Martin C, Daniel N, Frank SJ, Centonze VE, Herman B, Djiane J \& Gertler A 2003 Ovine placental lactogen-induced heterodimerization of ovine growth hormone and prolactin receptors in living cells is demonstrated by fluorescence resonance energy transfer microscopy and leads to prolonged phosphorylation of signal transducer and activator of transcription (STAT) 1 and STAT3. Endocrinology 144 3532-3540.

Cassy S, Charlier M, Belair L, Guillomot M, Charron G, Bloch B \& Djiane J 1998 Developmental expression and localization of the prolactin receptor (PRL-R) gene in ewe mammary gland during pregnancy and lactation: estimation of the ratio of the two forms of PRL-R messenger ribonucleic acid. Biology of Reproduction $\mathbf{5 8}$ 1290-1296.

Cassy S, Charlier M, Guillomot M, Pessemesse L \& Djiane J 1999 Cellular localization and evolution of prolactin receptor mRNA in ovine endometrium during pregnancy. FEBS Letters 445 207-211.

Cassy S, Charlier M, Belair L, Guillomot M, Laud K \& Djiane J 2000 Increase in prolactin receptor (PRL-R) mRNA level in the mammary gland after hormonal induction of lactation in virgin ewes. Domestic Animal Endocrinology 18 41-55.

Chilton BS \& Daniel JC 1985 Influence of Prolactin on DNA synthesis and glandular differentiation in rabbit uterine endometrium. In Prolactin Basic and Clinical Correlates, vol 1, pp 351-359. Eds RM MacLeod, MO Turner \& L Scapagnini. Pavoda, Italy: Liviana Press.

Chilton BS, Mani SK \& Bullock DW 1988 Servomechanism of prolactin and progesterone in regulating uterine gene expression. Molecular Endocrinology 2 1169-1175.

Chomczynski P \& Sacchi N 1987 Single-step method of RNA isolation by acid guanidinium thiocyanate-phenol-chloroform extraction. Analytical Biochemistry 162 156-159.

Gertler A, Grosclaude J, Strasburger CJ, Nir S \& Djiane J 1996 Realtime kinetic measurements of the interactions between lactogenic hormones and prolactin-receptor extracellular domains from several species support the model of hormone-induced transient 
receptor dimerization. Journal of Biological Chemistry 271 24482-24491.

Gray CA, Bartol FF, Tarleton BJ, Wiley AA, Johnson GA, Bazer FW \& Spencer TE 2001a Developmental biology of uterine glands. Biology of Reproduction 65 1311-1323.

Gray CA, Taylor KM, Ramsey WS, Hill JR, Bazer FW, Bartol FF \& Spencer TE 2001b Endometrial glands are required for preimplantation conceptus elongation and survival. Biology of Reproduction $641608-1613$.

Hansen TR, Imakawa K, Polites HG, Marotti KR, Anthony RV \& Roberts RM 1988 Interferon RNA of embryonic origin is expressed transiently during early pregnancy in the ewe. Journal of Biological Chemistry $26312801-12804$.

Herman A, Bignon C, Daniel N, Grosclaude J, Gertler A \& Djiane J 2000 Functional heterodimerization of prolactin and growth hormone receptors by ovine placental lactogen. Journal of Biological Chemistry 275 6295-6301.

Heyman Y, Camous S, Fèvre J, Meziou W \& Martal J 1984 Maintenance of the corpus luteum after uterine transfer of trophoblastic vesicles to cyclic cows and ewes. Journal of Reproduction and Fertility 70 533-540.

Kaluz S, Fisher PA, Kaluzova M, Sheldrick EL \& Flint AP 1996 Structure of an ovine interferon receptor and its expression in endometrium. Journal of Molecular Endocrinology 17 207-221.

Knickerbocker JJ \& Niswender GD 1989 Characterization of endometrial receptors for ovine trophoblast protein-1 during the estrous cycle and early pregnancy in sheep. Biology of Reproduction $\mathbf{4 0}$ $361-369$.

Lacroix MC, Devinoy E, Cassy S, Servely JL, Vidaud M \& Kann G 1999 Expression of growth hormone and its receptor in the placental and feto-maternal environment during early pregnancy in sheep. Endocrinology 140 5587-5597.

Leibovich H, Gertler A, Bazer FW \& Gootwine E 2000 Active immunization of ewes against ovine placental lactogen increases birth weight of lambs and milk production with no adverse effect on conception rate. Animal Reproduction Science 64 33-47.

Martal J, Djiane J \& Dubois MP 1977 Immunofluorescent localization of ovine placental lactogen. Cell and Tissue Research 184 427-433.

Martal J, Lacroix MC, Loudes C, Saunier M \& Wintenberger-Torres S 1979 Trophoblastin, an antiluteolytic protein present in early pregnancy in sheep. Journal of Reproduction and Fertility $\mathbf{5 6}$ $63-73$.

Martal J, Chene N, Camous S, Huynh L, Lantier F, Hermier P, L'Haridon R, Charpigny G, Charlier M \& Chaouat G 1997 Recent developments and potentialities for reducing embryo mortality in ruminants: the role of IFN-tau and other cytokines in early pregnancy. Reproduction, Fertility and Development 9 355-380.

Martal J, Chene N, Huynh L, L'Haridon R, Reinaud P, Guillomot M, Charlier M \& Charpigny S 1998 IFN-tau: a novel subtype I IFN1. Structural characteristics, non-ubiquitous expression, structurefunction relationships, a pregnancy hormonal embryonic signal and cross-species therapeutic potentialities. Biochimie $\mathbf{8 0}$ $755-777$.

Noel S, Herman A, Johnson GA, Gray CA, Stewart MD, Bazer FW, Gertler A \& Spencer TE 2003 Ovine placental lactogen specifically binds to endometrial glands of the ovine uterus. Biology of Reproduction $68772-780$.

Ormandy CJ, Camus A, Barra J, Damotte D, Lucas B, Buteau H Edery M, Brousse N, Babinet C, Binart N \& Kelly PA 1997 Null mutation of the prolactin receptor gene produces multiple reproductive defects in the mouse. Genes and Development $\mathbf{1 1}$ $167-178$.

Puissant C \& Houdebine LM 1990 An improvement of the single-step method of RNA isolation by acid guanidinium thiocyanate-phenol-chloroform extraction. Biotechniques 8 148-149.

Randall GW, Daniel JC Jr \& Chilton BS 1991 Prolactin enhances uteroglobin gene expression by uteri of immature rabbits. Journal of Reproduction and Fertility 91 249-257.

Sakal E, Elberg G \& Gertler A 1997 Direct evidence that lactogenic hormones induce homodimerization of membrane-anchored prolactin receptor in intact $\mathrm{Nb2}-11 \mathrm{C}$ rat lymphoma cells. FEBS Letters $410289-292$

Sambrook J, Frish EF \& Maniatis T 1989 Molecular Cloning, 2nd edn. Cold Spring Harbor: Cold Spring Harbor Laboratory Press.

Spencer TE \& Bazer FW 1995 Temporal and spatial alterations in uterine estrogen receptor and progesterone receptor gene expression during the estrous cycle and early pregnancy in the ewe. Biology of Reproduction 53 1527-1543.

Spencer TE \& Bazer FW 2002 Biology of progesterone action during pregnancy recognition and maintenance of pregnancy. Frontiers in Bioscience 7 1879-1898.

Spencer TE, Gray A, Johnson GA, Taylor KM, Gertler A, Gootwine E, Ott TL \& Bazer FW 1999 Effects of recombinant ovine interferon tau, placental lactogen, and growth hormone on the ovine uterus. Biology of Reproduction 61 1409-1418.

Stewart MD, Johnson GA, Gray CA, Burghardt RC, Schuler LA, Joyce MM, Bazer FW \& Spencer TE 2000 Prolactin receptor and uterine milk protein expression in the ovine endometrium during the estrous cycle and pregnancy. Biology of Reproduction 62 $1779-1789$

Wooding FB, Morgan G, Forsyth IA, Butcher G, Hutchings A, Billingsley SA \& Gluckman PD 1992 Light and electron microscopic studies of cellular localization of oPL with monoclonal and polyclonal antibodies. Journal of Histochemistry and Cytochemistry $401001-1009$.

Young KH, Kraeling RR \& Bazer FW 1989 Effects of prolactin on conceptus survival and uterine secretory activity in pigs. Journal of Reproduction and Fertility 86 713-722.

Received 31 December 2003

First decision 25 February 2004

Accepted 30 April 2004 